\title{
MONITORING MICROPOLLUTANTS IN SURFACE AND SUBSURFACE RUNOFF IN THE SWIST RIVER BASIN, GERMANY
}

\author{
EKKEHARD CHRISTOFFELS \\ IBC Ingenieure and Erftverband, Germany
}

\begin{abstract}
A study was conducted from year 2012 to 2015 to monitor the pathways of runoff flow components from the landscape in the Swist river basin, near Bonn (Germany). For this purpose, an innovative strategy was developed to collect samples from surface and subsurface runoff under different land use directly before entering the Swist river system. Numerous locally applied pesticides, some frequently used pharmaceuticals, industrial chemicals and flame retardants were detected. The monitoring system used in the project is able to collect realistic entries into rivers stemming from runoff components for different land use areas.

Keywords: monitoring, micropollutants, pesticides, herbicides, landscape runoff components, surface flow, subsurface flow.
\end{abstract}

\section{INTRODUCTION}

Transport of substances from adjacent landscape, from urban areas and from the atmosphere into a water course is defined as substance input. Substance input may take place at defined points or without a clear spatial delimitation as diffuse inputs (Table 1). In terms of temporal type of discharge process substance inputs can also be distinguished: event-specific; episodic; and continuous flow.

The below mentioned spatial and temporal criteria must be taken into account for a coherent monitoring strategy. This is also true for monitoring of micropollutant substances, since they can reach the water course through a variety of pathways. Micropollutants include, for example, the following groups of substances: biocides, herbicides, corrosion inhibitors, disinfectants, flame retardants, industrial chemicals and pharmaceutical compounds. In the following text a newly developed monitoring strategy for systematic identification of micropollutant inputs into the water course from the runoff components of the landscape is presented.

Runoff components of the landscape are surface flow, subsurface flow (interflow) and groundwater flow (Fig. 1). Surface and subsurface flow are called direct flow, because these flow components are directly linked to rainfall events.

Reliable monitoring systems to qualify substance input from landscape runoff are rare. Thus, an innovative monitoring system using a newly invented device to collect samples was put into service by the Erftverband (Christoffels and Willkomm [3]). The device is employed to collect samples in order to determine substance concentrations from landscape runoff. To quantify volumes of discharge from overland flow, subsurface and groundwater flow, a precipitation runoff model (NASIMC, Casper et al. [4]) is applied throughout the research area, the Swist catchment.

\section{RESEARCH AREA}

The Swist, a tributary of the Erft river in the greater Rhine catchment (Germany), is a stream with a total length of 44 kilometres. The catchment area covers ca. $290 \mathrm{~km}^{2}$. The average precipitation height in the Swist region, measured at the mouth of the river at Weilerswist 
Table 1: Spatial and temporal criteria of substance inputs into rivers.

\begin{tabular}{|c|c|c|c|}
\hline & \\
\hline & Event & Episodic & Continuous \\
\hline Non-point & Surface Runoff & & $\begin{array}{l}\text { Atmospheric } \\
\text { depostion }\end{array}$ \\
\hline \multirow{3}{*}{ Point } & $\begin{array}{l}\text { Combined Sewer } \\
\text { Overflow }\end{array}$ & & $\begin{array}{l}\text { Direct Discharge } \\
\text { from Trade \& } \\
\text { Industry }\end{array}$ \\
\hline & $\begin{array}{l}\text { Seperate Sewer } \\
\text { Outflow }\end{array}$ & Drainage Flow & $\begin{array}{l}\text { Wastewater } \\
\text { Treatment Plant }\end{array}$ \\
\hline & Erosion & Subsurface Flow & Groundwater Flow \\
\hline
\end{tabular}

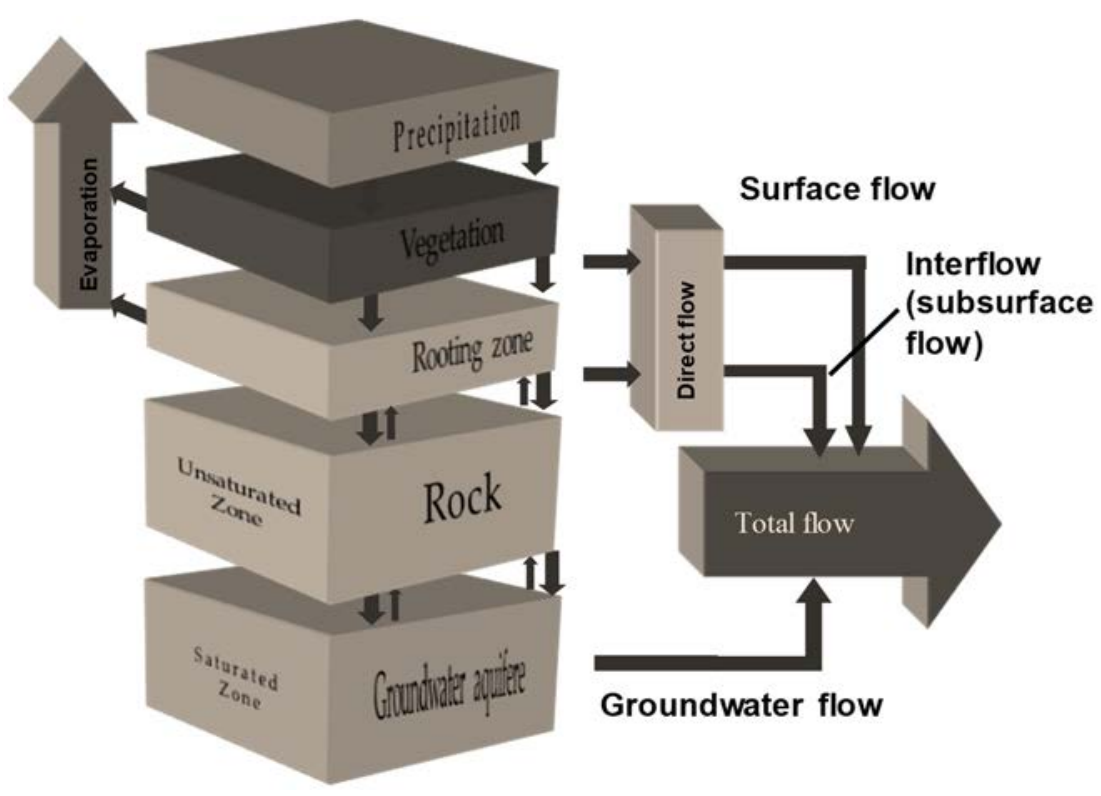

Figure 1: Runoff components of the landscape. (Source: Bogena et al. [1], modified by Christoffels [2].) 
from year 1972-2001, is $659 \mathrm{~mm} / \mathrm{a}$ (Kistemann et al. [5]). The Swist has an average water flow at the mouth of $830 \mathrm{~L} / \mathrm{s}$ (Weilerswist gauge 2014). In weather periods without rainfall many tributaries of the Swist dry out and the wastewater load in the Swist - coming from four small to middle sized WWTPs - is on average $40 \%$ of the overall water flow, with a maximum of $83 \%$. A total of nearly $30 \%$ of the catchment is forested. The climatic situation and fertile loess soils allow intensive agricultural use (4\% arable land, predominantly wheat, maize and sugar beet). Orchards are also characteristic in the catchment area (Fig. 2). About $95 \%$ of farmland is located at a distance of less than 500 metres from the waters; $10 \%$ is less than 50 metres from the waters (Christoffels et al. [6]).

In the upper reaches of the Swist the water course can be characterised as the type loessclay dominated lowland brook, in the lower reaches as gravel dominated lowland brook, modified by strong anthropogenic influences.

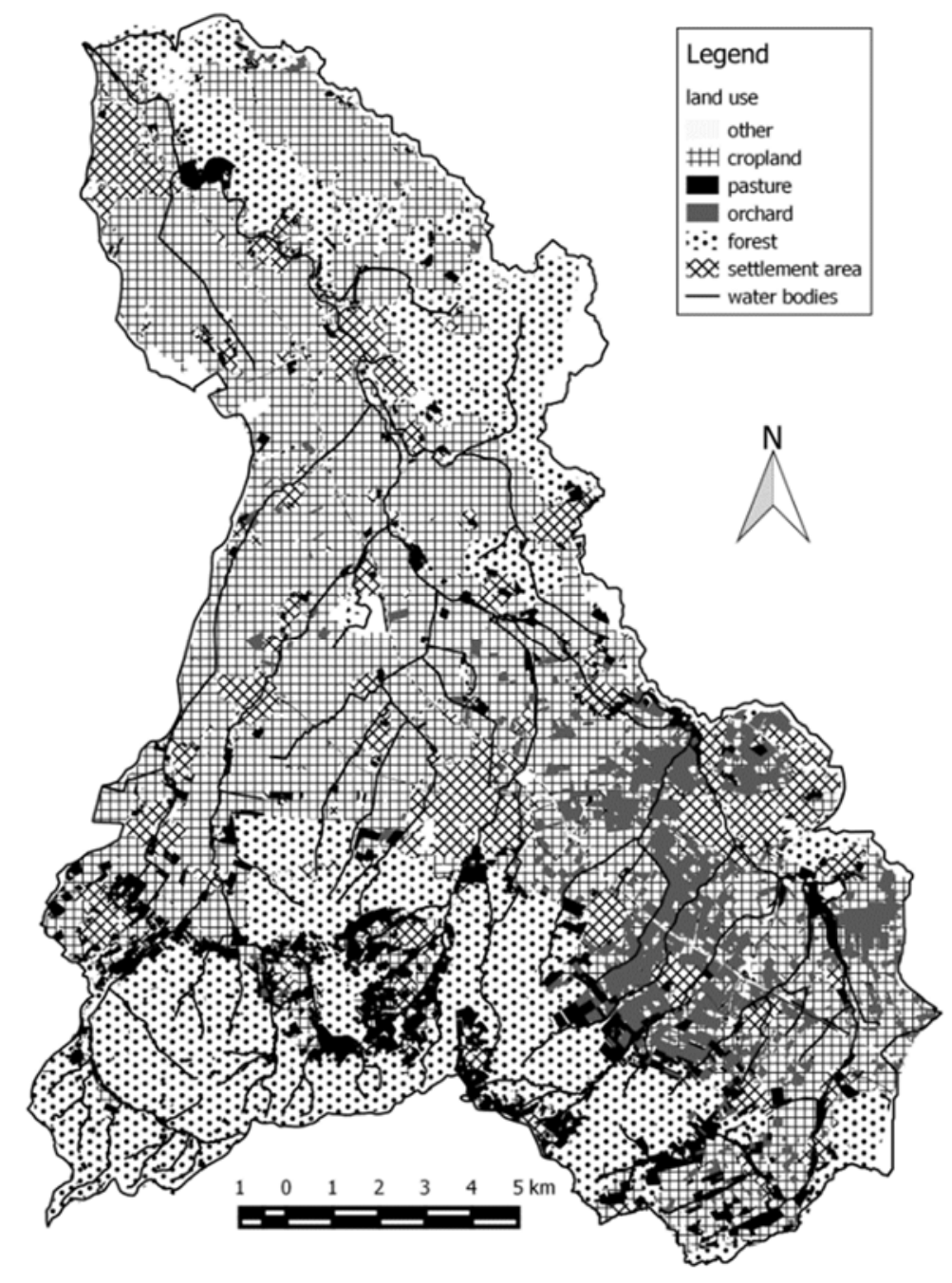

Figure 2: Land use in the Swist catchment area. (Source: Brunsch et al. [7].) 
Table 2: Swist catchment fact sheet. (Source: Kistemann T. et al. [5].)

\begin{tabular}{|c|c|c|}
\hline 1. & Size of catchment & $289 \mathrm{~km}^{2}$ \\
\hline 2. & Length of Swist water course & $43.6 \mathrm{~km}$ \\
\hline 3. & Elevation & $330 \mathrm{~m}-108 \mathrm{~m}$ above sea level \\
\hline \multirow[b]{2}{*}{4.} & \multirow[b]{2}{*}{ Type of cross section profile } & Upper reach: nearly natural \\
\hline & & $\begin{array}{l}\text { Middle and lower reach: technically } \\
\text { developed trapezoidal flume }\end{array}$ \\
\hline 5. & Population (total) & 91,700 inhabitants \\
\hline \multirow{2}{*}{6.} & \multirow{2}{*}{ Average water temperature (1996 - 2004) } & Upper reach: $9.9^{\circ} \mathrm{C}\left(\min .-\max .: 2-17^{\circ} \mathrm{C}\right)$ \\
\hline & & Lower reach: $11.7^{\circ} \mathrm{C}\left(\min .-\max .: 2-22^{\circ} \mathrm{C}\right)$ \\
\hline \multirow{2}{*}{7.} & \multirow{2}{*}{ Water flow at the mouth $(1985-2014)$} & MQ: $0.83 \mathrm{~m}^{3} / \mathrm{s}(\mathrm{MQ}=$ mean water flow) \\
\hline & & MNQ: $0.20 \mathrm{~m}^{3} / \mathrm{s}(\mathrm{MNQ}=$ mean low water flow) \\
\hline 8. & Number of WWTPs & $\begin{array}{l}4(10,000-50,000 \mathrm{PT} ; \mathrm{PT}=\text { total no. of } \\
\text { inhabitants \& population equivalents })\end{array}$ \\
\hline 9. & Treated wastewater & $7,129,000 \mathrm{~m}^{3} / \mathrm{a}$ \\
\hline 10. & $\begin{array}{l}\text { Number of stormwater retention tanks } \\
\text { and CSOs }\end{array}$ & 52 \\
\hline 11. & Combined sewage outlet & $1,468,000 \mathrm{~m}^{3} / \mathrm{a}$ \\
\hline
\end{tabular}

From its source to its mouth the Swist belongs to biological water quality class II (moderately polluted, betamesosaprobe) (Kistemann et al. [5]). Other important facts on the catchment area are summarised in Table 2.

\section{MONITORING STRATEGY}

The runoff from surface and subsurface was collected in purpose-built rectangular boxes sunk into the ground. The sampling device permitted separate capture of runoff from surface (overland flow) and subsurface flow from land under various utilizations. Four distinct land uses, which are typical for the Swist catchment area, were considered:

- $\quad$ Forest (1 monitoring point)

- Pasture (1 monitoring point)

- Cropland (4 monitoring points)

- Orchard (1 monitoring point)

Monitoring sites were chosen for their pertinence and representativeness. Landscape runoff from cropland was surveyed in the greatest detail, because it is the dominant land use type in the Swist catchment. Most of the monitoring points were located on public land, for example on sides of fields or in riparian zones, with the consent of farmers who utilized adjacent land areas. To prevent vandalism, the monitoring equipment was placed as inconspicuously as possible. In Fig. 3 the installation of a sampling device is depicted. The analyzed runoff parameters were the same for each type of land use. They included, among others, nutrients, alkaline and alkaline earth metals, heavy metals, pesticides and pharmaceuticals (Christoffels et al. [6]). 


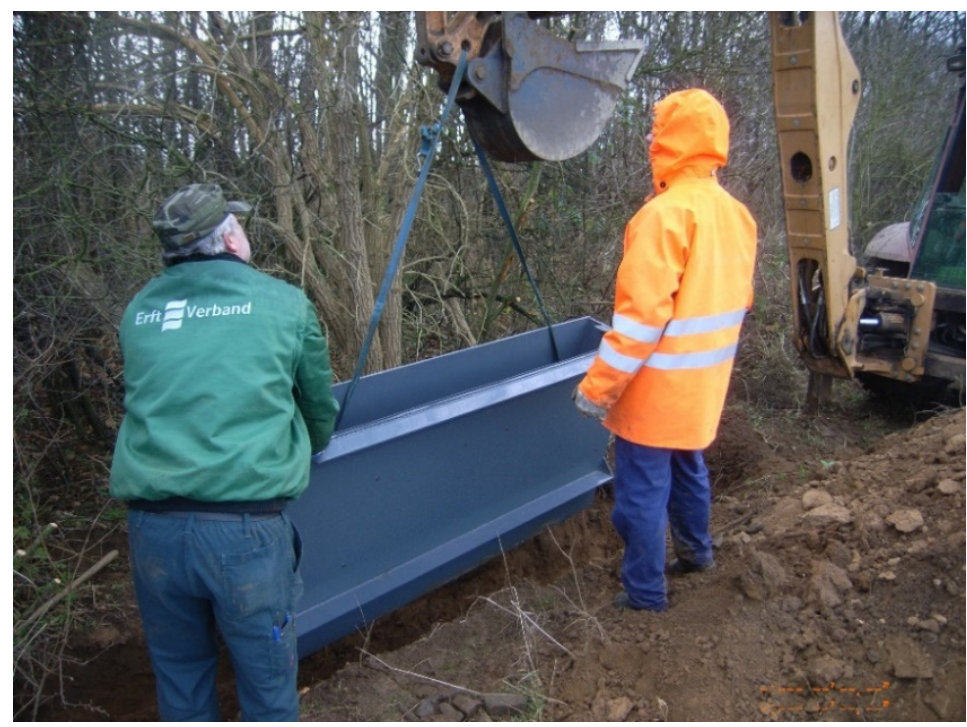

Figure 3: Installation of a sampling device in the Swist river basin. (Source: Erftverband, 2009.)

The sampling device (Figs 4 and 5) consists of a rectangular box of dimensions $2000 \mathrm{~mm}$ (length) x $300 \mathrm{~mm}$ (width) x $1000 \mathrm{~mm}$ (height), made of PVC-U (U = unplasticized). The box is embedded in the soil right along the water course. It is oriented lengthwise to the water course and crosswise to the direction of horizontal landscape runoff. The long side facing away from the water course is perforated on its entire surface with holes of $3 \mathrm{~mm}$ diameter. The water enters the device and is collected in detachable collection pans. The upper edge of the box is at surface level and covered with a thin layer of soil. A squeegee which is fixed horizontally on the perforated board enables separate influx of the surface and subsurface flow. One collection pan within the box collects surface runoff and a second, subjacent pan catches subsurface runoff from the soil matrix. Each pan has a holding capacity of 50 litres. To track and measure the filling process sensors are installed in the collection pans. The filling level is transmitted daily via SMS to the staff. In order to ensure a complete data set, the batteries for the recording unit have to be charged regularly (Christoffels et al. [6]).
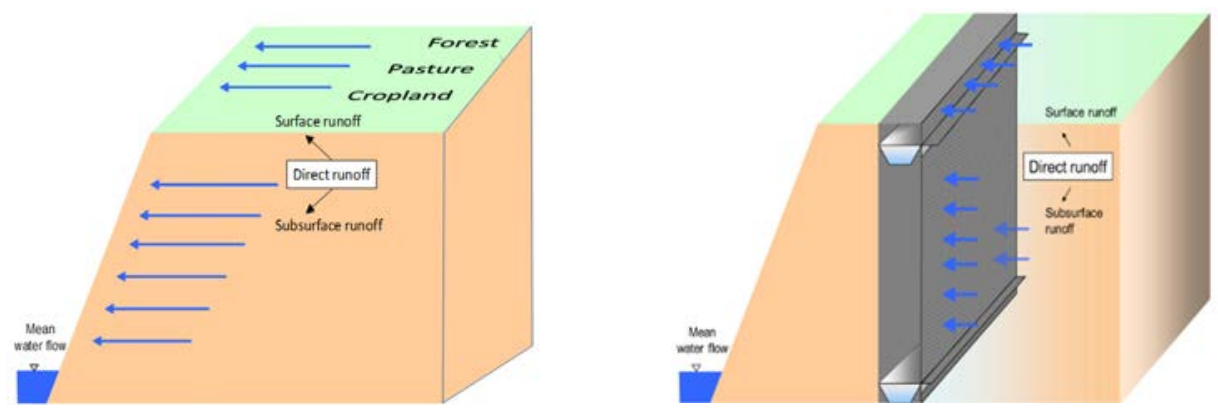

Figure 4: Schematic diagram of the sampling system. (Source: Christoffels [8].) 


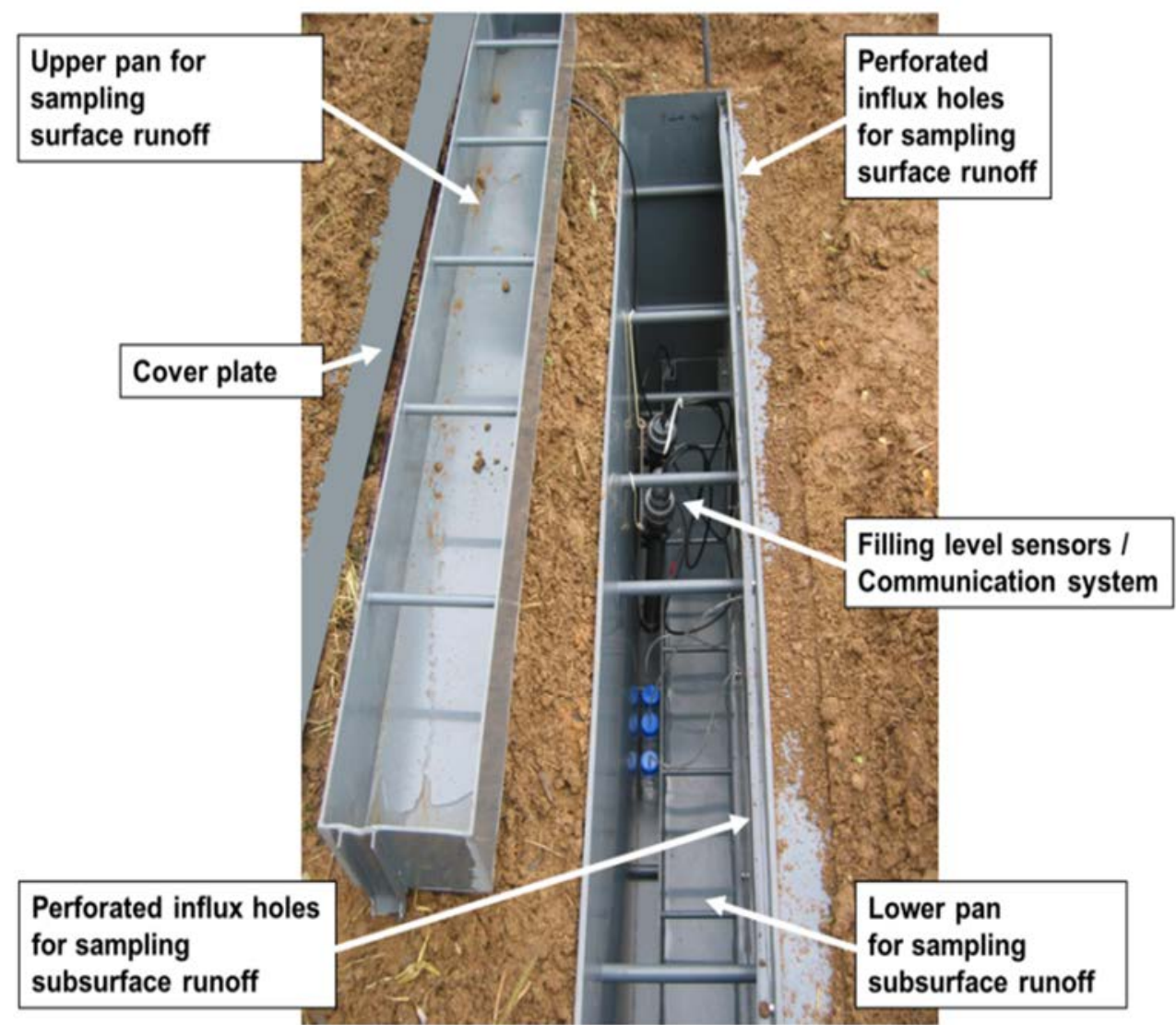

Figure 5: Sampling system (box) in opened state. (Source: Christoffels and Willkomm [3].)

The samples must be representative of real-life conditions. Accordingly, the measuring system should interfere with the natural soil structure and soil surface as little as possible. Hence it is important to preserve the natural soil matrix as best as possible during installation. The natural direction of surface runoff and subsurface water flow should be able to restore itself with a minimum of delay. From experience, it takes one to two years to obtain viable data for substance concentrations of both surface and subsurface runoff.

\section{RESULTS AND DISCUSSION}

The measurement data obtained in the monitoring campaign for micropollutants in the Swist river basin were analyzed. The most relevant parameters are shown in Table 3 classified into substance groups.

Investigations of diffuse substance inputs revealed a remarkable load of micropollutants in the agricultural area of the river basin. Fig. 6 shows the relative frequency of positive findings at the sampling points of farmland and orchard. Nearly all micropollutants which were found in runoff of arable land were also detected in runoff of orchards. In the following the main fields of application of the detected micropollutants are mentioned. 
Chloridazone is a selective herbicide, which is predominantly used in beet cultivation. Terbuthylazine is applied as a broad-spectrum herbicide in citrus, maize, vine and apple crops, as well as in forest and non-crop land. Benzotriazole is a corrosion inhibitor used in coolants, antifreezes, de-icing and descaling agents. In dishwashing detergents, it serves as silver protection. Caffeine is the main ingredient of coffee. Epoxiconazole is a fungicidal

Table 3: Classification of relevant micropollutants (measured values above detection limit in point and non-point pathways of the Swist river basin). (Source: Christoffels et al. [6].)

\begin{tabular}{|c|c|c|c|c|}
\hline \multicolumn{2}{|l|}{ Biocide } & \multirow{2}{*}{\begin{tabular}{|l} 
Metazachlor \\
Methabenzthiazuron
\end{tabular}} & \multirow{2}{*}{$\frac{\mathrm{x}}{\mathrm{o}}$} & \multirow{2}{*}{$\begin{array}{l}\text { Flame retardant } \\
\text { TCEP }\end{array}$} \\
\hline Diuron & 0 & & & \\
\hline Terbutryn & 0 & Metobromuron & $\mathrm{x}$ & TCPP \\
\hline \multicolumn{2}{|l|}{ Fungicide/Biocide } & Metolachlor & 0 & Industrial chemical \\
\hline Tebuconazole & $\mathrm{x}$ & Metribuzin & $\mathrm{x}$ & 2,4-Dichlorobenzoic acid \\
\hline \multicolumn{2}{|l|}{ Fungicide } & Napropamid & $\mathrm{x}$ & Triphenylphosphin oxide \\
\hline Epoxiconazol & $\mathrm{x}$ & Nicosulfuron & $\mathrm{x}$ & Pharmaceutical compound \\
\hline Fenpropidin & $\mathrm{x}$ & Pendimethalin & $\mathrm{x}$ & Atenolol \\
\hline Fenpropimorph & $\mathrm{x}$ & Prometryn & $\circ$ & Bisoprolol \\
\hline Metconazol & $\mathrm{x}$ & Prosulfocarb & $\mathrm{x}$ & Carbamazepine \\
\hline Propiconazol & $\mathrm{x}$ & Simazine & 0 & Clarithromycin \\
\hline \multicolumn{2}{|c|}{ Transformation product fungicide } & Terbuthylazine & $\mathrm{x}$ & Diclofenac \\
\hline Dimethylsulfamid & & Triclopyr & $\mathrm{x}$ & Erythromycin \\
\hline \multicolumn{2}{|l|}{ Herbicide/Biocide } & Triflusulfuron & $\mathrm{x}$ & Ibuprofen \\
\hline $2,4-\mathrm{D}$ & $\mathrm{x}$ & Quinmerac & $\mathrm{x}$ & Metformin \\
\hline Clopyralid & $\mathrm{x}$ & \multicolumn{2}{|c|}{ Transformation product herbicide } & Metoprolol \\
\hline Dicamba & $\mathrm{x}$ & Atrazin-desethyl-2-hydroxy & & Naproxen \\
\hline Flufenacet & $\mathrm{x}$ & Chloridazon-Desphenyl & & Phenazon \\
\hline Fluroxypyr & $\mathrm{x}$ & Chloridazon-Desphenyl-Methyl & & Propranolol \\
\hline MCPA & $\mathrm{x}$ & Desethylterbuthylazin & & Roxithromycin \\
\hline Mecoprop (MCPP) & $\mathrm{x}$ & Terbuthylazin-2-hydroxy & & Sotalol \\
\hline \multicolumn{2}{|l|}{ Herbicide } & Desisopropylatrazine & & \begin{tabular}{|l} 
Sulfadiazine \\
\end{tabular} \\
\hline Atrazin & 0 & Desethylatrazine & & Sulfadimidine \\
\hline Bentazone & $\mathrm{x}$ & \multicolumn{2}{|l|}{ Insecticide } & Sulfamethoxazole \\
\hline Chloridazon & $\mathrm{x}$ & Chlorpyrifos & 0 & Trimethoprim \\
\hline Chlortoluron & $\mathrm{x}$ & Diflubenzuron & o & Stimulator \\
\hline Dichlorprop & $\mathrm{x}$ & Imidacloprid & $\mathrm{x}$ & Caffeine \\
\hline Dimethenamid & $\mathrm{x}$ & \multicolumn{2}{|l|}{ Corrosion inhibitor } & $\mathrm{X}$-ray contrast media \\
\hline Ethidimuron & 0 & 1H-Benzotriazole & & Diatrizoat \\
\hline Ethofumesat & $\mathrm{x}$ & \multicolumn{2}{|l|}{ Disinfectant } & Iohexol \\
\hline Isoproturon & $\mathrm{x}$ & Triclosan & & Iomeprol \\
\hline Lenacil & $\mathrm{x}$ & \multicolumn{2}{|l|}{ Mosquito repellent } & Iopamidol \\
\hline Metamitron & $\mathrm{x}$ & DEET & & Iopromid \\
\hline
\end{tabular}



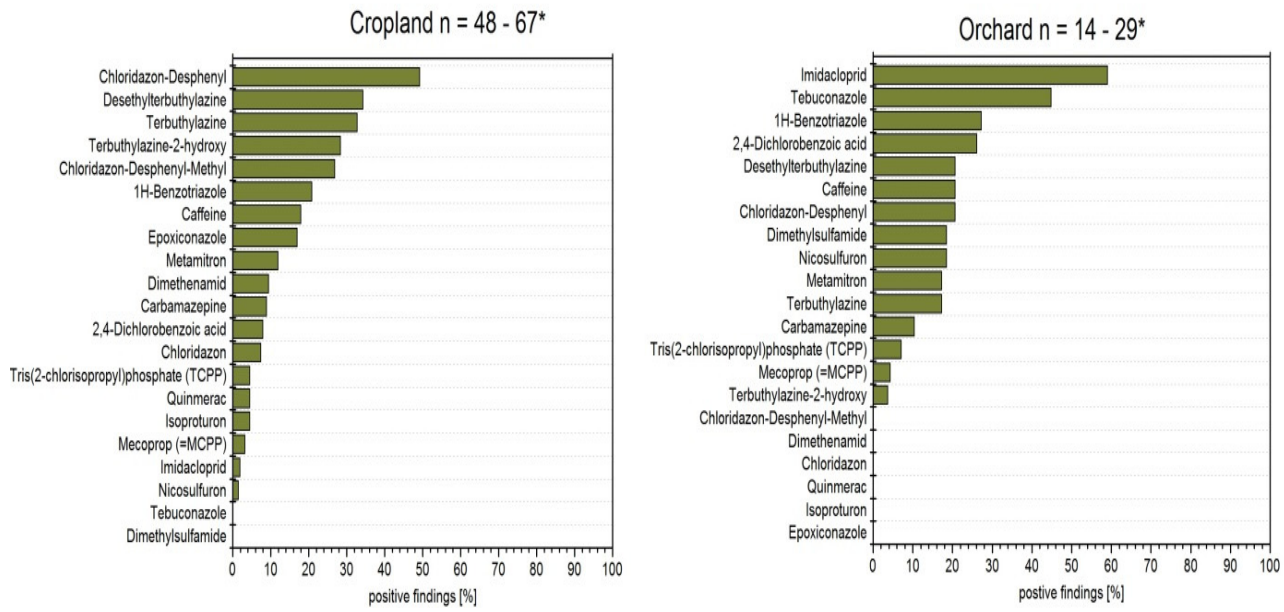

Figure 6: Relative frequency of positive findings of micropollutants in landscape runoff from cropland and orchard (study period 2012-2015, *differences in the number of analyses (n) per parameter due to increased laboratory capability). (Source: Christoffels et al. [6].)

active ingredient that prevents the growth and sporulation of fungi. Metamitron is applied as herbicide in beets against seed weeds. Dimethenamid is used as herbicide mainly in corn and beet, but also in legume (soybean) and sunflower cultivation. Carbamazepine is an anticonvulsant used primarily to treat epilepsy. Dichlorobenzene acid is used for the production of 2,4-dichlorobenzoic acid which is applied for the production of colorings and pharmaceuticals. TCPP is used as a flame retardant. The widespread use of TCPP in plastics and the fact that it cannot be efficiently removed in sewage treatment plants is the reason that it is present in surface waters (Kemmlein et al. [9]). Quinmerac is used as herbicide against weeds in cereal, rapeseed and sugar beet cultivation. Isoproturon is preferably used as herbicide for winter wheat, winter barley, rye, spring barley and summer wheat. MCPP (Mecoprop) is an herbicide against broadleaf weeds such as thistles, dandelions, etc. Mecoprop is also used as an anti-rooting agent in roofing felt. Imidacloprid is an insecticide used in sugar and feed beet, cereals, potatoes, corn, onions and oil pumpkin. Nicosulfuron is applied as herbicide in maize. Tebuconazole is used as a fungicide. Tebuconazole is also added to wood preservatives as a fungicidal active ingredient. Dimethylsulfamide is a metabolite of the fungicides Dichlofluanid and Tolylfluanid.

In the samples of farmland 19 micropollutants were detected during the monitoring period from 2012 to 2015, 15 micropollutants in samples of orchard. The frequency of detection depended on the substance, between 2 and 59\% of all samples taken. Particularly, on arable land the herbicides Chloridazon and Terbuthylazine or their metabolites were found. In orchards the insecticide Imidacloprid dominated with $59 \%$ positive findings as well as the fungicide Tebuconazole with $45 \%$ positive findings. The study showed that micropollutants to a considerable extent can enter the river from arable land via surface and subsurface flow (Christoffels et al. [6]). 


\section{CONCLUSION}

Many different micropollutants, mainly herbicides, were detected in the runoff from the landscape. Application of pesticides for protection of field crops is the main reason. Drugs, stimulants and industrial chemicals were also found. These can come from the application of manure and sewage sludge on fields as fertilizer. Particularly as a consequence of precipitation events with previous application of pesticides, increased inputs into the watercourses can be expected. The innovative monitoring system used in the project is able to collect realistic entries into rivers stemming from runoff components for different land use areas. The monitoring system has proven itself over many years under operation.

\section{ACKNOWLEDGEMENTS}

The studies presented here were carried out with funds provided by the European Union Life+ project "Application of Integrative Modelling and Monitoring Approaches for River Basin Management Evaluation", the Interreg IVb NWE project "Transnational Action Program on Emerging Substances" and the project "Evaluation of measures to reduce physical, chemical and microbiological loads in rivers with the example of the Swist river" funded through the Ministry for Climate Protection, Environment, Agriculture, Conservation and Consumer Protection of NRW (Germany). Thanks also to B. Smallberg and the colleagues from the Erftverband and the Institute for Hygiene and Public Health, Bonn University.

\section{REFERENCES}

[1] Bogena, H., Kunkel, R., Schöberl, T., Schrey, H.-P. \& Wendland, F., Die Grundwasserneubildung in Nordrhein-Westfalen, Schriften des Forschungszentrums Jülich, Reihe Umwelt, 37, Forschungszentrum Jülich GmbH, 148 S, (Groundwater Recharge in North Rhine-Westphalia, Research Centre Jülich (Germany)), 2003.

[2] Christoffels, E., Monitoring and Modellanwendung - Entwicklung eines Immissionsinventars am Beispiel der Erft (Monitoring and Model Application Development of an Immission Inventory with the Example of the Erft River), Erftverband, Bergheim, 2008.

[3] Christoffels, E. \& Willkomm, M., Chemisch-physikalische Stoffeinträge in die Fließgewässer aus den Abflusskomponenten des Landschaftswasserhaushaltes - Teil 1: Konzeption des Monitoringsystems und grundlegende Ergebnisse (Physico-chemical substance inputs into rivers from runoff components of the landscape- Part 1: Design of the monitoring system and basic results). Korrespondenz Wasserwirtschaft, 1(11), pp. 612-617, 2008.

[4] Casper, M., Herbst, M., Grundmann, J., Buchholz, O. \& Bliefernicht, J., Einfluss der Niederschlagsvariabilität auf die Simulation extremer Abflüsse in kleinen Einzugsgebieten (Influence of Rainfall Variability on Simulation of Extreme Runoff in Small River Basins). Hydrologie und Wasserbewirtschaftung, 53(3), 2009.

[5] Kistemann, T. et al., Mikrobielle Fließgewässerbelastungen durch abwassertechnische Anlagen und diffuse Einträge (Microbial water course charges from wastewater treatment plants and diffuse inputs) Ministerium für Umwelt, Naturschutz, Landwirtschaft und Verbraucherschutz NRW, 2009.

[6] Christoffels, E., Brunsch, A., Wunderlich-Pfeiffer, J. \& Mertens, F.-M., Monitoring micropollutants in the Swist river basin. Water Science and Technology, 2016. wst2016392; DOI: 10.2166/wst.2016.392. 
[7] Brunsch, A.F., Mertens, F.M. \& Christoffels, E., Eintragspfade von Spurenstoffen im Flusseinzugsgebiet der Swist (Input Pathways of Micropollutants in the Swist River Basin). Wasser und Abfall, 15(11), pp. 38-42, 2013.

[8] Christoffels, E., Chemisch-physikalische Stoffeinträge in die Fließgewässer aus den Abflusskomponenten des Landschaftswasserhaushaltes - Teil 2: Technik, Ergebnisse und Plausibilitätsuntersuchungen (Physico-chemical substance inputs into rivers from runoff components of the landscape- Part 2: technology, results and plausibility checks). Korrespondenz Wasserwirtschaft, 4(10), pp. 548-552, 2011.

[9] Kemmlein, S., Hahn, O. \& Jann, O., Emissionen von Flammschutzmitteln aus Bauprodukten und Konsumgütern (Emissions of Flame Retardants from Building Material and Consumer Products), Umweltforschungsplan des Bundesumweltministeriums für Umwelt, Naturschutz und Reaktorsicherheit Forschungsbericht 29965, 2003. 